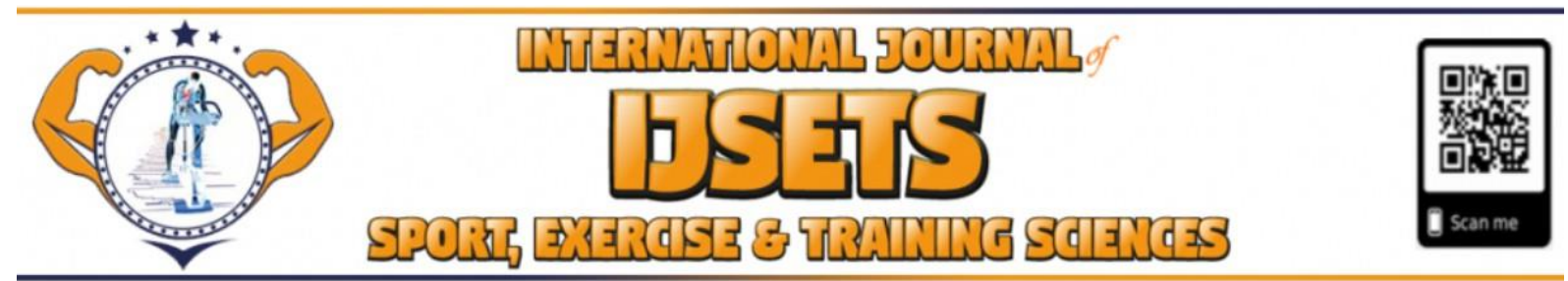

e-ISSN 2149-8229

Vol 7, Issue 2, 60-72, (2021)

Original Article

http://dergipark.gov.tr/useeabd

\title{
Kaygılarım Kabusum Olmasın! Futbolcuların Covid-19 Pandemisi Sürecindeki Kaygılarının Fotoses Yöntemiyle İncelenmesi
}

\author{
Okan ÜNVER ${ }^{1}$, Halime DİNÇ ${ }^{2}$, Esra ÇETİN ${ }^{3}$, Metin ARGAN $^{4}$ \\ Özet \\ Amaç: Bu çalışmada Covid-19 pandemisinden etkilenen futbolcuların bu süreçte yaşadıkları \\ kaygı durumlarının fotoses yöntemiyle ortaya konulması amaçlanmıştır. \\ Materyal ve Metot: $\mathrm{Bu}$ çalışma için nitel araştırma yöntemlerinden fotoses yöntemi \\ kullanılmıştır. Araştırmaya Türkiye liglerinde futbol oynayan 5 amatör ve 4 profesyonel olmak \\ Keywords \\ Covid-19, \\ Kayg1, \\ Futbolcu, \\ Fotoses
} üzere 9 futbolcu dahil edilmiştir. Katılımcılardan toplam 33 fotoğraf ve hikaye toplanmış olup 11 fotoğraf ve hikaye araştırma kapsamında kullanılmıştır. Katılımcılarla yapılan görüşmeler yardımıyla fotoğraflar ve hikayeler, araştırmacı ve katılımcıların fikir birliği ile tematik içerik analizi yöntemi ile temalandırılmıştır.

Bulgular: Araştırma bulguları olarak 4 ana tema ve 9 alt tema ortaya koyulmuştur. Bu temalar sosyal kaygı ana teması altında sosyal mesafe, evde kal ve paylaşım yoksunluğu alt teması, ekonomik kaygı teması altında var olanı koruma ve yoklukla mücadele alt teması, gelecek kaygısı teması altında güzellikleri kaçırma, plan ve rutinleri 1skalama alt teması, son tema olarak ise sağlık teması altında aile bireyine virüs bulaştırma ve kendini virüsten koruyabilme alt teması olarak belirlenmiştir.

Sonuç: Virüsle ilgili aşının ve tedavinin bulunamamış olması, karantina ve önlem süreçleri, küresel ekonomik daralma ve belirsizlik sürecinin katılımcılarının kaygılarını oluşturduğu belirlenmiştir. Araştırma sonuçları, sporcuların psikolojik sıkıntılarının giderilmesi ve önlenmesi adına karar vericilere yardımcı olacaktır.

Yavin Bilgisi

Gönderi Tarihi: 11.09 .2021

Kabul Tarihi: 31.10 .2021

Online Yayın Tarihi: 15.12.2021

DOI:10.18826/useeabd. 830125

\section{Don't Let My Worries Be My Nightmare! Investigation of Football Player's Worries During the Covid-19 Pandemic Process Using Photovoice}

\section{Abstract}

Aim: In this study, it was aimed to reveal the worry situations experienced by the football players affected by the Covid-19 pandemic with the photovoice method.

Methods: For this study, the photovoice method, one of the qualitative research methods, was used. Research on playing football in Turkey have been included nine players, including five professional and four amateurs. 33 photos and stories were collected from the participants, and 11 photos and stories were included in the research. Through interviews with participants, the photos and stories were themed with the consensus of the researchers and the participants through the thematic content analysis method.

Results: As a result of the research, 4 main themes and 9 sub-themes were emerged. These themes are social distance, stay at home and lack of communion sub-themes under the main theme of social worry, preservation of existing and fighting poverty sub-themes under the theme of economic worry, missing beauties, and missing plans and routines under the theme of future worry, as the last theme, it was determined as the sub-theme of transmitting viruses to the family member and protecting itself from the virus under the theme of health worry.

Conclusion: It has been determined that the lack of vaccine and treatment related to the virus, quarantine and precautionary processes, global economic recession, and uncertainty process are the worries of the participants. The results of the research will help decision-makers to eliminate DOI:10.18826/useeabd.830125 and prevent the psychological problems of athletes.

\section{GíRiş}

Aralık 2019'un sonlarında Çin'in Wuhan şehrinde yeni koronavirüs hastalığının (Covid-19) salgını başlayarak hızla dünyanın diğer ülkelerine yayılmıştır (Xu vd., 2020). SARS-CoV ve MERS-CoV gibi

\footnotetext{
The role and contributions of each authors as in the section of IJSETS Writing Rules "Criteria for Authorship" is reported that: 1. Author: Contributions to the conception or design of the paper, data collection; 2. Author: Data collection, preparation of the paper according to rules of the journal, final approval of the version to be published paper; 3. Author: Statistical analysis, interpretation of the data and final approval of the version to be published paper.

${ }_{1}^{1}$ Corresponding Author: Faculty of Sport Sciences, Çanakkale Onsekiz Mart University, Çanakkale/Turkey, okanunver@gmail.com ORCID ID: 0000-00029271-3395

${ }^{2}$ Faculty of Sport Sciences, Afyon Kocatepe University, Afyon/Turkey halimedinc@yandex.com, ORCID ID: 0000-0002-2391-5508

${ }^{3}$ Faculty of Sport Sciences, Pamukkale University, Denizli/Turkey, cetinesra@yahoo.com, ORCID ID: 0000-0003-1528-570X

${ }^{4}$ Faculty of Sport Sciences, Eskişehir Technical University, Eskişehir/Turkey, margan@ eskisehir.edu.tr, ORCID ID: 0000-0002-9570-0469
} 
koronavirüs ailesinin diğer üyeleri ile karşılaştırıldığında, Covid-19'un daha düşük bir ölüm oranı olduğu görülmektedir. Bununla birlikte, bu virüsün yüksek bulaşma hızı, ayrıca aşı eksikliği ve Covid19 için bazı farmasötik tedaviler, hastalık yayılımının kontrolünde ciddi zorluklar yaratmıştır (Abdulamir, Ahmet \& Rand, 2020). Bu tür sorunları çözmek için, kişisel koruma uygulamalarının geliştirilmesi (örneğin yüz maskelerinin kullanılması ve kişisel hijyen takibi), seyahat kısıtlamalarının uygulanması ve muhtemel enfekte vakalarda sosyal mesafenin korunması gibi tıbbi olmayan önlemlerin uygulanması gerekmektedir.

Covid-19, 20 Mayıs 2020 tarihine gelindiğinde dünya çapında 4,9 milyon insana bulaşıp hasta etmiş aynı zamanda 323 bin kişinin ölümüne sebep olmuştur. Türkiye'deki vaka/ölüm durumu incelendiğinde ise 151 bin hasta ve 4199 ölüm gözlenmektedir (Google, 2020). Pandemi süreci bütün iş kollarını etkilemiş olmakla beraber futbol endüstrisine de büyük darbe vurmuştur. Ülkemizdeki bütün futbol müsabakaları 19 Mart 2020 tarihinde ertelenmiş olup, 12 Haziran 2020 tarihinde süper lig düzeyinden başlamak üzere tekrar başlatılmasına Türkiye Futbol Federasyonu (TFF) tarafından karar verilmiştir (TFF, 2020).

Pandemi sürecinden geçerken insanların hastalığa yakalanma durumunun ötesinde zihinsel sağlık ihtiyaçlarını belirlemek nispeten ihmal edilmiş bir konu olarak karşımıza çıkmaktadır (Xiang vd., 2020). Kitlesel trajedilerin, özellikle de bulaşıcı hastalıkları içerenlerin, genellikle popülasyondaki birçok kişinin davranışında ve psikolojik refahında büyük bozulmalara neden olduğu artan korku ve endişe dalgalarını tetiklediği göz önüne alındığında şaşırtıcı sonuçlar oluşturmaktadır (Balaratnasingam \& Janca, 2006). Örneğin yakın zamanda Covid-19 enfeksiyonu kapsamında uygulanan bir çalışmada, travmatik stresin yaygınlık oranı \%73.4, depresyon \%50.7, genel anksiyete $\% 44.7$ ve uykusuzluk \%36.1 gibi psikolojik rahatsızlıklar yüksek oranlarda karşımıza çıkmaktadır (Liu vd., 2020).

Futbol ve Covid-19: Bütün dünyayı etkisi altına alan Covid-19 pandemisi, futbol endüstrisini ve paydaşlarını da olumsuz yönde etkilemiş durumdadır. Virüs nedeniyle Avrupa kulüplerinde birçok futbolcu ve teknik heyet yetkilisi Covid-19 hastalığına yakalanmıştır (Goal, 2020a). Ülkemizde ise Galatasaray spor kulübünün teknik direktörü Fatih Terim ve kulüp yöneticileri virüs nedeniyle Covid19 hastalığına yakalanmıştır (Euronews, 2020, 1 Haziran). Pandeminin olumsuz etkilerinden kendini korumak isteyen Avrupa ülkeleri ligleri ertelemiştir. Fransa, Hollanda ve İskoçya'da ligler 2019-2020 sezonu için bir daha oynanmamak için tescil edilirken diğer ülke federasyonları ileri bir tarihte maçların oynanmasına karar vermiştir (Goal, 2020b).

Ertelenen ligler nedeniyle gelir kaybına uğrayan birçok futbol kulübü futbolcularından maaş indirimi talep etmiştir (The Guardian, 2020). Futbolcular, kulüplerin bu isteklerine büyük ölçüde olumlu tepki vermiştir. Tabi ki bu süreçte başarı odaklı olan kulüplerin en büyük problemlerinden biri de futbolcuların toplu şekilde antrenman yaptıramamak olmuştur. Avrupa'nın önde gelen takımlarından Bayern Münih, bu sıkıntı üzerine futbolcularına zoom uygulaması üzerinden online antrenmanlara başlamış ve birçok kulüp bu yöntemi uygulamıştır (Spencer, 2020, 28 Mayıs).

Hemen hiç kimsenin alışkın ve hazırlıklı olmadığı bu süreç futbolcular üzerinde olumsuz etkiler yaratmıştır. Bu olumsuzlukları bertaraf edebilmek adına Manchester United kulübü futbolcularının fiziksel ihtiyaçlarını antrenmanla karşılamanın yanı sıra psikolojik destek vermeye karar vermiştir (Duncker, 2020).

Bütün bu olaylar yaşanırken bazı futbol paydaşları endişelerini dile getirmekten kaçınmamış ve bu süreçte Trabzonspor futbolcusu John Obi Mikel ve Chelsea futbolcusu Engolo Kante gibi birçok futbolcu virüsü evlerine, ailelerine taşıma ve hasta olma endişesiyle antrenman ve maçlara çıkmayı reddetmiştir (Alistair, 2020, 1 Haziran).

Kaygı: Türk dil kurumunun tanımlamasına göre kayg1, "üzüntü, endişe duyulan düşünce, tasa" anlamına gelmektedir (TDK, 2020). Bir diğer tanıma göre ise, bireyin herhangi bir uyaranın etkisine girmesiyle bedenen, ruhen ve zihnen yaşadığı değişimler sonucu beliren bir uyarılma halidir. Kaygı, derecesine göre hafif düzeyde yaşanan tedirginlik halinden yüksek düzeyde yaşanan panik haline kadar çeşitli düzeylerde hissedilebilen bir duygu durumdur (Dinçer, 2010).

Bireyler kendi doğaları gereği gelecekleriyle ilgili plan yapma ve planlamış oldukları geleceklerine güven duymak istemektedirler. Geleceklerinde yaşamak istedikleri güven ortamının tehdit altında olması durumunda endişe hissetmektedirler. Gelecekle ilgili belirsizliğin yaşandığı ortamlarda, bireylerin kaygı seviyelerinde kayda değer artış gözlenmektedir (Büyüköztürk, 1997). 
Literatürde kaygıdan temelde iki çeşit olarak bahsedilmiştir. Bunlar durumluk kaygısı ve sürekli kaygı halidir. Fakat sosyal kaygı ve gelecek kaygısı tanımları da yer almaktadır.

Durumluk kaygı, geçici olarak veya kısa bir süre için yaşanır. Kişiye acı hissi yaşatan ve tedirginlik hali oluşturan bir duygudur (Horwitz, 2001). Durumluk kaygısı, bilişsel etkileri olan geçici bir duygusal deneyimdir (MacIntyre, 1995).

Sürekli kaygı, uzun süre kaygı hissetmek için nedenler bulan insanların, kişilik özelliği olarak bilinmektedir (Scovel, 1978). Bazı insanlar, her gün yaşadıkları birçok durumda endişeli veya rahatsız hissederler. Günlük yaşamlarında karşılaştıkları şeylere karşı kendini rahatsız hissetmek için nedenler bulabilirler. Bu onların kaygılarının kişilik temelli olduğunu göstermektedir. Sürekli kaygı, kişilik temelli kaygı olarak da adlandırılır ve "bireyin her durumda endişeli olma olasıllı̆̆" olarak tanımlanır (Hofman \& Smits, 2008).

Gelecek kaygısı, bireylerin gelecekleriyle ilgili yaşadıkları ümitsizlik durumu ve herhangi bir durum sonucunda karamsarlık yaşama gibi durumlarda ortaya çıkmaktadır. Gelecek kaygısı canlılar içerisinde sadece insanlarda görülmektedir. İnsanlar, zamanın farkına varılmasını sağlayan zihin ötesi genler sayesinde bir geleceği olduğunu fark eder ve o geleceği kontrol edemeyeceğini hissettiğinde kaygı hissi yaşamaya başlar (Tarhan, 2012).

Sosyal kaygı ise, bireyin toplum tarafindan biçilmiş olan rollere uygun davranmayacağı, topluluk içinde zor duruma düşeceği, toplulukta kötü izlenim yaratabileceği tedirginliği ile hissetmiş olduğu rahatsız ve gerilimli bir duygu durumdur (Dilmaç \& Baş, 2019).

Pandemi Sürecindeki Kaygı: Kaygı, belirsizliğe ve bize zarar verebilecek şeylere normal bir tepki olarak görülmektedir. Covid-19 ve benzer salgınlar insanlar için gerçek anlamda belirsizlik içeren bir süreçtir ve bu süreçte bireyler kendilerinin ve sevdiklerinin sağlığlyla ilgili endişe içerisindedir. İnsanlar sağlı endişesinin yanı sıra okul, iş, ekonomi, sosyal etkinliklere ve hobilere katılma ve hayatlarının diğer önemli bölümleri hakkında yaşadıkları birçok endişe ile yüz yüze olma durumundadırlar (Heretohelp, 2020).

Toplumdaki kaygı ve endişeler küresel olarak her bireyi değişken boyutlarda etkilemektedir. Son araştırma bulguları, izolasyonda ve karantinada tutulan bireylerin anksiyete, öfke, karmaşa ve travma sonrası stres belirtileri şeklinde önemli sıkıntı yaşadıklarını göstermekle beraber (Brooks vd., 2020) halkın bu durum üzerindeki bilgi ve tutumlarının, kişisel koruyucu önlemlere ve nihayetinde klinik sonuca bağlılık derecesini büyük ölçüde etkilemesi beklenmektedir.

Araştırmalar sonucunda herhangi bir salgın durumunda insanlarının yüksek düzeyde endişe hissettiği (Taylor, Kingsley, Garry \& Raphael, 2008) ve yakın zamanda hayatımızı etkileyen sars virüsünün yarattığı salgın üzerine Hong Kong'da gerçekleştirilen araştırmada insanların yaşadığı çaresizlik ve stres seviyelerinin yükseldiği belirlenmiştir (Lau, Kim, Tsui \& Griffiths, 2007). Yine sars virüsü sonucunda oluşan salgın üzerinde yapılan çalışmada, insanların hastalanma ya da bu virüs nedeniyle ölme olasılıkları nedeniyle endişe düzeylerinin yükseldiği (Leung vd., 2005), fakat demografik değişkenlere göre endişe seviyesinin farklılık gösterdiği, örneğin kadınlarda, orta yaş grubunda ve eğitim seviyesi düşük olan katılımcılarda endişe seviyesinin çok yüksek olduğu sonucuna ulaşılmıştır. Jones ve Salathé (2009)'nin çalışmasına göre insanlarını domuz gribi salgının başlangıcında endişelerinin yüksek olduğu fakat ilerleyen süreçte azaldığı belirlenmiştir. İnsanların endişe düzeylerinin, salgın sürecinde alacak oldukları önlemler üstünde etkili olduğunun belirlenmesi de çalışmanın kayda değer bir bulgusu olarak karşımıza çıkmaktadır.

Covid-19 pandemisinin insanlar üzerinde oluşturduğu endişeler son zamanlarda araştırmalara konu olmaktadır. Amerika, İngiltere ve Almanya'yı kapsayan bir araştırmada insanların ailelerinin hayatı, ülkelerinin ekonomik istikrarı, psikolojik sağlkları, kendi ekonomik durumları, işlerinin güvende olması gibi durumlarda endişelerinin olduğu saptanmıştır (Statista, 2020). Yine İngiltere'de yapılan bir başka çalışmada, Twitter kullanıcılarının pandemi sürecindeki duygu durumları ve olası kaygılarının araştırılmasında, katılımcıların \%55 gibi yüksek bir oranda süreci kaygıyla takip ettiği ve kayg1 duydukları durumlar olarak ise işleri, ekonomik durumları, ölüm, aileleri ve arkadaşları olarak belirlenmiştir (Kleinberg, Van Der Vegt \& Mozes, 2020).

Virüsün etkisi altında bulunun insanlar sağlık konusunda büyük kaygı hissetmektedir. İnsanların sağlıkla ilgili kaygıları genellikle sevdiklerinin, kendilerinin ve sağlık sisteminin üzerine yoğunlaşmıştır. Covid-19 nedeniyle ciddi bir hastalığa yakalanma ve hatta ölebilme durumu insanlar için önemli bir endişe kaynağı olarak belirlenmiş olup insanların, arkadaşlarının ve ailelerinin sağlığı 
hakkında endişelenebilmesi başka bir endişe kaynağı olarak belirlenmiştir. Covid-19 ile ilgili raporlar, yaşlıların ve sağlıksız kişilerin özellikle Covid-19 enfeksiyonu nedeniyle ciddi sağlık sorunlarına maruz kalma riski taşıdığını gösterdiğinden, insanlar özellikle yaşlı akrabalar veya kronik hastalıkları olan sevdiklerinden endişe içinde olabilecekleri aktarılmıştır (Mertens, Gerritsen, Selamink \& Engelhard, 2020; Kleinberg vd., 2020).

$\mathrm{Bu}$ süreçte yaşanan kaygıların bir başka çeşidi olarak sosyal kaygılar karşımıza çıkmaktadır. Ülkeler pandemiyi engellemek için karantina, seyahat kısıtlamaları ve sosyal mesafe gibi tıbbi olmayan önlemler almak zorundadır. Bütün bu kısıtlamaların, insanların belirsizlik sürecinde sosyal kaygılarını arttırdığı gözlenmiştir (Roy vd., 2020; Mertens vd., 2020).

Pandeminin yarattığı ekonomik kaygılar üzerine Amerika'da yapılan çalışmada insanların Google arama motorunda yaptıkları aramalar incelenmiştir. Bu incelemede pandemi öncesi ve sonrası olarak sınıflama yapılmış olup virüsün ülkeye girişi ardından ekonomik durgunlukla ilgili yapılan aramaların $\% 17$ arttığı ve borsadaki olası çöküşle alakalı aramaların ise \%58 arttığı gözlemlenmiştir. Katılımcıların Amerika ekonomisi için kaygı oranları \%87 oranında bulunmuş olup yine aynı katılımcıların kişisel ekonomik durumları nedeniyle yaşadığı kaygı oranı \%77 bulunmuştur. Araştırma bulguları, ekonomik kaygıların ve krizin algılanan şiddetinin, Covid-19'la beraber önemli ölçüde arttığını vurgulamaktadır (Fetzer, Hensel, Hermle \& Roth, 2020).

Görünüşe göre, hastalığın yayılmasını ve diğer endişe verici durumları önlemek için çeşitli düzeylerdeki çabalara ek olarak, toplumun ruh sağlı̆̆ sorunlarına özel dikkat gösterilmelidir. Covid19 yeni bir hastalık olduğundan ve küresel olarak yıkıcı etkilere sahip olduğundan, ortaya çıkışı ve yayılması, halk arasında karışıklığa, endişeye ve korkuya neden olmaktadır.

Her ne kadar Covid-19 pandemisiyle ilgili çalışmalar yapılmış olsa da çalışmaların birçoğu sağlık alanını kapsamaktadır. Bu süreçten etkilenen bireylerin psikolojik durumları nispeten göz ardı edilmiş durumdadır. $\mathrm{Bu}$ bağlamda çalışmamızın amacı, kısıtlamalar sebebiyle pandemiden etkilenen futbolcuların bu süreçte yaşadıkları kaygı durumlarının fotoses yöntemiyle ortaya çıkarılmasıdır.

\section{MATERYAL ve YÖNTEM}

\section{Katılımcilar}

Türkiye liglerinde bütün maçlar Covid-19 nedeniyle ertelendiğinden, aktif lisansa sahip bütün futbolcular bu olumsuzluktan etkilenmiştir. Araştırmamız için amaçlı örneklem yöntemlerinde uygun örnekleme yöntemi kullanışmıştır. Uygun örnekleme vakit, para, konum ve cevap veren gibi koşullara bağlı olan ve bu koşullara göre örneklem seçilebilen bir yöntemdir (Merriam, 2013). Mevcut pandemi kısıtlamalarında ulaşılabilen futbolcularla, aktif lisansa sahip olma ve isteğe cevap verme kriterleri çerçevesinde yapılan ön görüşmeler sonucu, katılım sağlamaya gönüllü olan 4'ü profesyonel, 5 'i amatör toplam 9 futbolcu araştırmaya dahil edilmiştir. Katılımcıların gizliliğinin sağlanması adına katılımcılar sahip oldukları lisansa göre A (amatör futbolcu) ve P (profesyonel futbolcu) şeklinde numaralandırılarak kodlanmıştır. Araştırmanın etik kurul onayı, Eskişehir Teknik Üniversitesi'nden 14.07.2020 tarih ve E.16756 sayı ile elde edilmiştir.

\section{Araştırma deseni ve verilerin toplanması}

Araştırma nitel araştırma yöntemlerinden fotoses yöntemiyle gerçekleştirilmiştir. Fotoses yöntemi, belirlenmiş olan tema dahilinde katılımcıların kendi bakış açılarıyla araştırmaya dahil oldukları bir süreçtir (Booth ve Booth, 2003). Üyelerin kendi bakış açıları ve katılımı sayesinde, deneyim ve fikirlerinin ortaya konması sonucu elde edilecek veriler son derece önemlidir (Argan, Yılmaz, Argan \& Yetim, 2020). Yöntem için kullanılan fotoğraflar tartışma için bir katalizör görevi görebilir, tanımlanması zor olan durumları görsel olarak belgeleyebilir (psikolojik durumlar gibi) ve "bir resim bin kelimeye bedeldir' mottosuyla sosyal değişimi teşvik eden, empati ve anlayışı ortaya çıkarabilir (Wang \& Burris, 1997). Fotoses, ilk olarak 1994 yılında Wang ve Burris tarafindan kullanılan ve insanların fotoğrafik teknikle kendilerini ifade ettikleri katılımcı bir eylem araştırmasıdır (Wang \& Burris, 1994). Bir grubun içerisinde bulunduğu dezavantajlı durumu fotoğraflama yardımıyla kaydederek yansitmak, mevcut dezavantajlı durumları ile ilgili hikayelerini ortaya çıkarmak, fotoğraflar üzerinden oluşturulan tartışmalar yardımıyla bilgi üreterek durumun karar vericilerin dikkatini çekmesini sağlamayı ve dezavantajlı durumun düzeltilmesini amaçlamaktadır (Lopez, Eng, Robinson \& Wang, 2005). 
Yöntemin, futbolcuların pandemi döneminde yaşadıkları kaygıyı belirlemekte kullanımı uygundur. Çünkü, günümüzde en popüler spor dalı olan futbolun (Huerta, 2004) paydaşı olan futbolcular, spor karar vericilerine seslerini duyurmakla birlikte mevcut sistemde gerekli düzenlemelirin yapılmasına ön ayak olma potansiyelini barındırmaktadır (Goodheart vd., 2006).

Tablo 1. Fotoses yönteminin süreci (Argan, Y1lmaz, Argan \& Yetim, 2020)

1. Grubun oluşturulması

2. Temanın katılımcılarla birlikte tanımlanması

3. Fotoğrafların çekilmesi

4. Fotoğraf seçimi ve bağlamlaştırma

5. Temaları, sorunları ve teorileri kodlamak

6. Grup diși karar vericileri hedefleme

Çalışmaya dahil edilen katılımcılarla normal şartlarda toplantı ortamında gerçekleştirilmesi gereken görüşmeler, Covid-19 nedeniyle telefon üzerinden yapılmıştır. Futbolcularla yapılan görüşmeler ortalama 23 dakika $(\mathrm{SS}: 2,8)$ sürmüş olup kayıt altına alınmıştır. Her bir katılımcı aranarak Covid-19 sürecinde yaşamış oldukları kaygıları fotoğraflaması istenmiştir. Araştırmaya kendi telefonlarının kamerasıyla dahil olan katılımcılara belirli sokağa çıkma kısıtlamaları ve mümkün olduğunca evde kalınması gereken bu dönemde kendi çekecekleri fotoğrafların yanı sıra internet ortamından onlar için kaygıyı ifade edecek görsellerin de araştırmaya dahil edileceği belirtilmiştir. Katılımcılarla beraber belirlenen üç haftalık süre sonunda 33 adet fotoğraf ve katılımcıların fotoğrafla ilgili düşüncelerini belirttikleri hikayeler toplanmıştır. $\mathrm{Bu}$ süre sonrasında tekrar görüşülen katılımcılardan kaygıyı en iyi temsil ettiklerine inandıkları fotoğrafları seçmeleri istenmiştir. İkinci görüşmenin ardından katılımcıların belirlediği 11 fotoğraf çalışmaya dahil edilmiştir. Görüşmenin amacı çalışmanın hedeflediği temayı yansıtabilecek fotoğrafların seçilerek hikayesinin anlatılması ve kavramlaştırılmasıdır. Katılımcılara 'fotoğrafı bana anlat', 'fotoğrafta neler oluyor' gibi sorular yöneltilerek fotoğrafin hikayesinin anlatılası teşvik edilmiştir.

\section{İstatistiksel Analiz}

Çalışmamızın analizi için tematik içerik analiz kullanılmıştır. Tematik içerik analizi, belirlenmiş olan bir konu dahilinde gerçekleştirilen araştırmanın temalandırılması veya belirli bir çerçeveye oturtulmasını sağlayarak, eleştirel bir bakış açısıyla incelenmesi ve yorumlanmasıdır. Araştırma konusunun, bir bütün olarak derinlemesine incelenmesine olanak tanımaktadır (Çalık \& Sözbilir, 2014). Tematik içerik analizi yardımıyla fotoğraflar içerikleri ve hikayelerine göre temalara ayırılmış ve katılımcılarla görüşülerek bu temalar tartışılmıştır. Bu görüşmedeki hedef, üye denetimini 3 katılımc1 (a1, p3 ve a4) ile yaparak güvenilirliği sağlamaktır. Üye denetimi (member check), nitel araştırma yöntemlerinde güvenilirliği belirlemek için kullanılan bir yöntemdir. Üye denetimi, bulguların kısa bir özetini ya da tüm bulguları araştırma katılımcılarıyla paylaşmak olarak tanımlanmaktadır (Lincoln \& Guba, 1985). Araştırmacı ve katılımcılar arasında gerçekleştirilen görüşmelerde bütün temalar üzerinde fikir birliği sağlanmıştır.

\section{BULGULAR}

Çalışma katılımcılarından, fotoğraflar ve grup tartışmaları yoluyla Covid-19 sürecinde yaşamış oldukları kaygıları belirlemeleri istenmiştir. Toplanan veriler 1şığında 4 ana tema belirlenmiştir: (1) Sosyal kaygı, (2) Ekonomik kaygı, (3) Gelecek kaygısı ve (4) Sağlık kaygısı.

Tablo 2. Katılımcıların kaygılarının temalandırılması

\begin{tabular}{|c|c|c|c|c|}
\hline \multicolumn{2}{|c|}{ Ana temalar Sosyal kayg1 } & Ekonomik kayg1 & Gelecek kaygisı & Sağlık kaygısı \\
\hline \multirow[t]{3}{*}{ Alt temalar } & Sosyal mesafe & Var olanı koruma & Güzellikleri kaçırma & $\begin{array}{l}\text { Aile bireylerine virüs } \\
\text { bulaştırma }\end{array}$ \\
\hline & Evde kal & Yoklukla mücadel & lan ve rutinleri sskalama & $\begin{array}{l}\text { Kendini virüsten } \\
\text { koruyabilme }\end{array}$ \\
\hline & Paylașim yoks & & & \\
\hline
\end{tabular}

Sosyal kaygı, katılımcıların sosyalleşme ortamındaki kaygılarını temsil ederken, ekonomik kaygı ise pandeminin olumsuz ekonomik etkilerinin oluşturduğu kaygıları ortaya koymaktadır, gelecek kaygısı ise temelde sporcuların kendileri ve çevresindekilerin gelecekleri ile ilgili kaygıları içermekte 
olup son olarak sağlık kaygısı, Covid-19'un sağlıkla ilgili bilinen tehditlerine karşı yaşadıkları kaygıları kapsamaktadır. Her bir tema ve kendisini oluşturan alt temalara ilişkin ayrıntılı açıklamalar aşağıda verilmiştir.

\section{Sosyal Kaygı}

Katılımcılar ve araştırmacılar tarafından belirlenen fotoğrafların 3'ünün, katılımcıların Covid-19 sürecinde yaşamış oldukları sosyal kaygılarıyla ilişkili olduğu belirlenmiştir. Sosyal kaygı teması, katılımcıların Covid-19 sebebiyle mahrum kaldıkları sosyalleşme durumlarını içermektedir. Covid-19 pandemisi kişilerin sosyal alanlarını olabildiğince olumsuz etkilemiştir. Pandemi süreci için bu zamana kadar önleyici ve tedavi edici herhangi bir çözümün bulunmamış olması, kanun yapıcıları, insanların evde kalmaları ve sosyal mesafeyi korumalarına yönelik önlemlere itmektedir. Bu önlemler paralelinde sosyal kaygı teması, sosyal mesafe, evde kal ve paylaşım yoksunluğu alt temalardan oluşmaktadır. Sosyal kaygı ile ilişkili fotoğraf ve hikaye örnekleri tablo 3 'te gösterilmiştir.

Tablo 3. Sosyal Kayg1

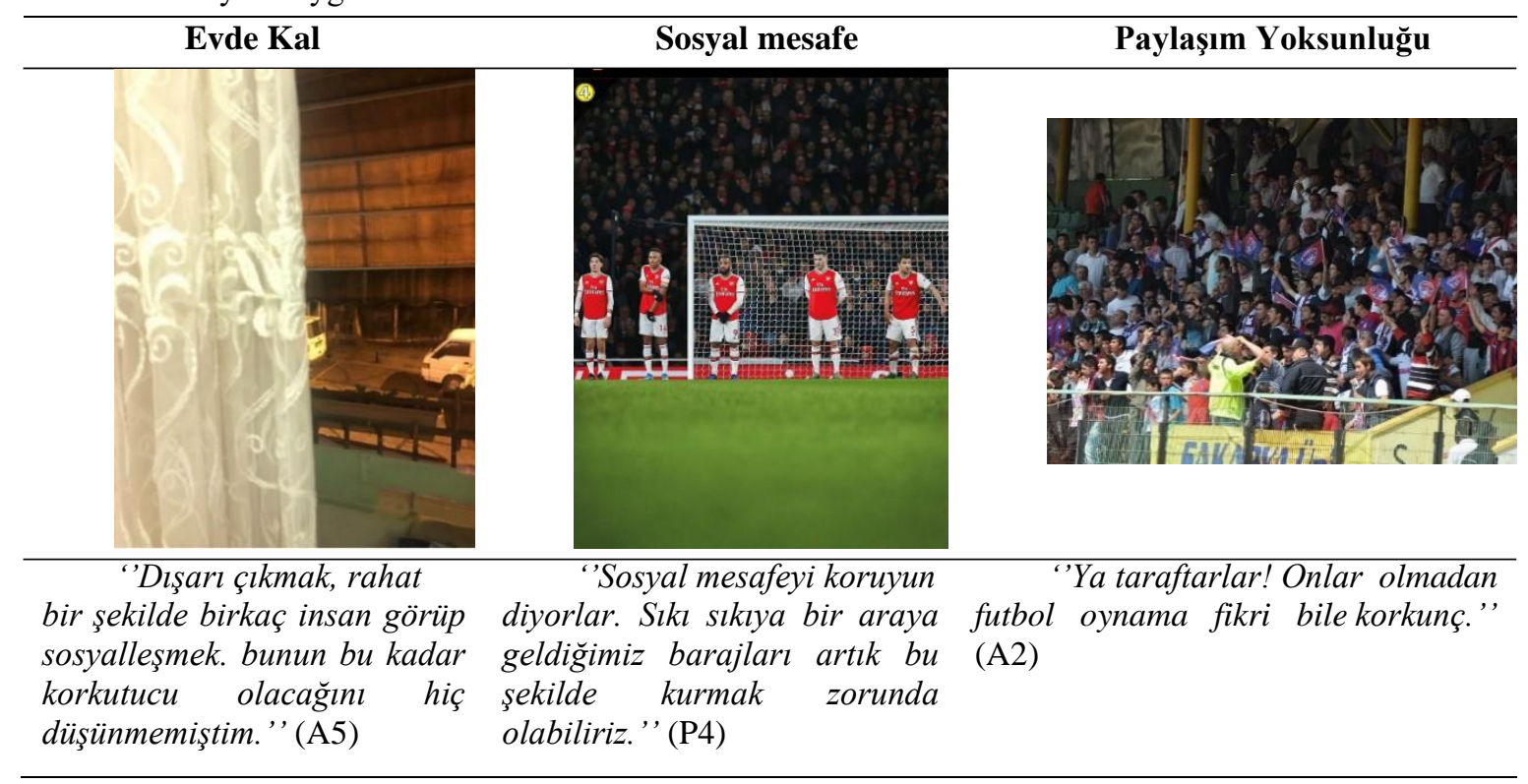

Evde Kal: Evde kal alt teması altında belirlenen hikayelerin incelenmesinde bir katılımc1, 'Dışarı çıkmak, rahat bir şekilde birkaç insan görüp sosyalleşmek. bunun bu kadar korkutucu olacağını hiç düşünmemiştim.(A5)" diyerek evde kalması gerektiğini ve bu durumu evinin penceresinde kapalı bir perdenin arkasından bomboş bir sokağı fotoğraflayarak resmetmiştir. Katılımcıyla yapılan görüşmede hayatı boyunca böyle bir durumla karşılaşmadığını ve bu süreçte yaşanan belirsizliğin onu kaygıya ittiğini söylemiştir.

Sosyal mesafe: Sosyal mesafe alt temasında ise başka futbolcu 'Sosyal mesafeyi koruyun diyorlar. Sıkı sıkıya bir araya geldiğimiz barajları artık bu şekilde kurmak zorunda olabiliriz. (P4)' sözüyle iç içe oynanan futbolda bunun ne kadar imkansız olduğunu resmetmiştir. Futbolcuyla yapılan görüşmede ise bire bir mücadelenin yoğunlukla yaşandığı futbol müsabakalarının pandemi süreci bitmeden sosyal mesafesiz bir şekilde oynanmasının mümkün olmadığını ve sosyal mesafe kuralına uygunsuz şekilde oynamak zorunda olduğu futbolun onu kaygılandırdığını söylemiştir.

Paylaşım Yoksunluğu: Sosyal kaygıyı oluşturan bir başka alt tema olan paylaşım yoksunluğu alt temasinda 'Ya taraftarlar! Onlar olmadan futbol oynama fikri bile korkunç. (A2)"' hikayesiyle taraftarlı oynanan bir maçtaki tribünlerin fotoğrafinı çalışmaya dahil etmiştir. Katılımcıyla gerçekleştirilen görüşmede daha önce cezalar sebebiyle taraftarsız maçlar oynadığını fakat pandemi sürecindeki durumun farklı olduğunu belirtmiştir. Katılımcı taraftarlarla paylaşım içinde olmanın ekstra motive kaynağı olduğunu ve taraftarsız, paylaşımsız maçların antrenmandan farksız olacağını ve bu süreçte onlardan ne kadar ayrı kalacağının bile belli olmadığını ifade etmiştir. 


\section{Ekonomik Kaygı}

Yine katılımcı ve araştırmacıların ortaklaşa seçmiş olduğu fotoğrafların 2'si, katılımcıların bu süreçte yaşamış oldukları ekonomik kaygılarla ilişkilendirilmiştir. Ekonomik kaygı teması, katılımcıların resim ve hikayelerinden çıkarımla Covid-19 sürecinde yaşamış oldukları ekonomik sıkıntıların oluşturduğu kaygıları temsil ederken var olanı koruma ve yoklukla mücadele alt temalarından oluşmaktadır. Ekonomik kaygıyla ilişkili fotoğraf ve hikaye örnekleri tablo 4 'te gösterilmiştir.

Tablo 4. Ekonomik Kayg1

\begin{tabular}{ccc}
\hline Var olanı koruma & Yoklukla mücadele \\
\hline \\
kramponlara talim ederiz. ", (A4)
\end{tabular}

Var Olanı Koruma: Ekonomik kaygının alt temalarından var olanı koruma teması dahilinde belirlemiş olduğumuz hikayelerin incelenmesinde ise katılımo "'Bu parasızlık böyle devam ederse yırtık kramponlara talim ederiz.(A4) " ifadesini kullanmıştır. Futbolcunun eski bir kramponunu çekmiş olduğu fotoğraf üzerine yapılan görüşmede ise pandemi sürecinde maçların ertelenmiş olduğunu ve para kazanamadığını, mevcut ekonomik durumu neticesinde ise var olanı korumakta bile zorlanacağını belirtmiștir.

Yoklukla Mücadele: Bir diğer katılımc1 ise yoklukla mücadele alt temasında 'Param bitiyor, haftalardır para kazanamıyorum. Ya parasız kalırsam.(A1)" hikayesi üzerine cebinden çıkardığ1 birkaç bozuk parayı fotoğraflamıştır. Bu katılımcıyla yapılan görüşmede ise pandeminin yaratmış olduğu ekonomik sıkıntı nedeniyle kulübünden para alamadığını ve bu durumun ne kadar süreceğinin belirsizliğiyle birlikte parasız kalma kaygısı yaşadığını belirtmiştir.

\section{Gelecek Kaygısı}

Katılımcıların pandemi sürecindeki yaşamış oldukları gelecek kaygısını resmedip hikayelendirdikleri fotoğraflar, gelecek kaygısı temasını oluşturmuştur. Bu tema altına toplanan fotoğraf ve hikayeler katılımcıların gelecekle ilgili belirsizlik ortamının bir çıktısını ortaya koymaktadır. Gelecek kaygısı temasının alt temaları olarak ise güzellikleri kaçırma, plan ve rutinleri ıskalama olarak belirlenmiştir. Gelecek kaygısı ile ilişkili fotoğraf ve hikaye örnekleri tablo 3 'te gösterilmiştir.

Tablo 5. Gelecek Kaygis1

Güzellikleri kaçırma
sürekli bu maskeyle mi kavuşabileceğim? Benim
gelecek hayalim bu değil." (P2)




\section{Güzellikleri Kaçırma}

Katılımc1 ''Güzelle, denizle, yeşille şimdilik baharla sürekli bu maskeyle mi kavuşabileceğim? Benim gelecek hayalim bu değil(P2)." hikayesiyle bir elinde maskeyle evinden denizi, yeşilliği ve gökyüzünü fotoğraflayarak gelecekte bu üçlüye kavuşma ihtimalini sorgulamıştır ve bu fotoğraf güzellikleri kaçırma alt temasına dahil edilmiştir. Katılımcı ile yapılan görüşmede mevcut şartlar dahilinde çok sevdiği bahar mevsimi ve onun güzelliklerini kaçırmak istemediğini fakat yine sürecin ne zaman sona ereceğini bilmemesiyle birlikte kaygı içinde olduğunu belirtmiştir.

Plan ve Rutinleri Iskalama: Diğer bir katılımc1 ise "Sevgilimle uzun yolculuklara çıkma hayalimi gerçekleştiremeyecek olmak. (P1)' ' notuyla otobüs seyahatinden bir fotoğrafla araştırmaya dahil olmuştur. Katılımcıyla gerçekleştirilen görüşmede, sezonun bitmesiyle birlikte kız arkadaşıyla tatil planladıklarını fakat bulunmuş olduğu ortam neticesiyle gelecekte planladıkları seyahati gerçekleştirememekle ilgili kaygı hissettiğini belirtmiştir.

\section{Sağlık Kaygısı}

Futbolcu katılımcı ve araştırmacılar tarafından seçilen fotoğraf ve hikayelerin oluşturmuş olduğu bir başka tema ise sağlık kaygısı temasıdır. Ortaklaşa belirlenen fotoğraflar, katılımcıların yaşamış olduğu sağlık kaygısını vurgulamaktadır. Bu temayı oluşturan fotoğraflarda, katılımcıların kendileri ve ailelerinin sağlıklarını koruma ve virüse yakalanmama içerikleri gözlemlenmiştir. Sağlık kaygısı temasının alt temaları ise, aile bireylerine virüs bulaştırma ve kendini virüsten koruyabilme olarak belirlenmiştir. Sağlık kaygısı ile ilişkili fotoğraf ve hikaye örnekleri tablo 6'da gösterilmiştir.

Tablo 6. Sağlık kaygısı

Aile bireylerine virüs bulaştırma

Aile Bireylerine Virüs Bulaştırma: Son tema olarak belirlenen sağlık kaygısı teması dahilinde yapılan incelemede bir katılımcı "Antrenmana, maça gitmek için dışarı çıkttğımda ya eve hastalık getirirsem.(A3)" hikayesiyle paylaştı̆̆ı fotoğrafta çalışmaya bir aile silueti ile dahil olmuştur. Fotoğrafı paylaşan futbolcu ile yapılan görüşmede, insanların sağlıklarını korumak için henüz herhangi bir önleyici ya da tedavi edici yöntemin bulunmamasıyla birlikte futbol oynamak için dişarı çıktığında eve virüsü taşıma ve bu virüsün ailesine zarar verme kaygısı yaşadığını belirtmiştir.

Kendini Virüsten Koruyabilme: Çalışmaya katılan futbolculardan bir diğeri ise ''Maske olmadan dı̧̧arı çıkarmıyorlar, futbol oyna diyorlar. Lanet hastalığa yakalanirsam kim alacak bunun sorumluluğunu?(P3) ', notuyla maske taktığı bir fotoğrafı paylaşmıştır. Futbolcuyla yapılan görüşmede liglerin iptal edilmeyip ertelenmesinin, pandemi ortamında yanlış olduğunu ve maske olmadan sosyal mesafe sağlansa bile dışarıya çıkamamasına rağmen futbol oynamasının istediğini ve bunun neticesinde hastalığa yakalanma ihtimaliyle kaygı duyduğunu belirtmiştir.

\section{TARTIŞMA}

Araştırmamızın temel amacı, futbolcuların Covid-19 sürecinde yaşamış olduğu kaygıların fotoses yöntemiyle temalandırılarak incelenmesidir. Çalışma kapsamında katılımcılardan gelen fotoğraf ve 
hikayelerin, araştırmacı ve katılımcıların ortaklaşa incelemesi sonucunda 4 ana tema ve 9 alt tema belirlenmiştir.

Futbolcuların sosyal kaygilarını ifade ettikleri tema, sosyal mesafe ve evde kal alt temalarından oluşmaktadır. Covid-19 pandemisinin henüz belirli bir tedavisinin olmaması ve aşının geliştirilememiş olması kanun yapıcıları tıbbi olmayan koruma önlemlerine mecbur bırakmaktadır. Virüsle mücadele eden ülkemizde ve birçok ülkede gerek zorunlu olarak gerekse gönüllü olarak insanların evde kalmaları istenmiştir (Güner, Hasanoğlu \& Aktaş, 2020). Bu süreçte yaşanan belirsizlikle birlikte kimsenin daha önce tecrübe etmeği bir durumla karşılaşmış olmak, katılımcıların sosyal mesafe ve evde kal temalarıyla kaygılarını ifade ettikleri fotoğraf ve hikayeler oluşturmalarına neden olmuştur. Daha önce yapılan çalışmalar bulgularımızı destekler nitelikte olup pandemi gibi belirsiz ve kısıtlamalar içeren süreçlerde insanların sosyal kaygı seviyelerinden önemli ölçüde artış gösterdiği belirtilmiştir (Roy vd., 2020). Pandemi sürecinde gerçekleştirilen bir başka çalışmada ise insanların evlerinde izole halde ne kadar kalacakları hakkındaki belirsizliğin onlara kaygı yaşattığı ortaya konmuştur (Mertens vd., 2020).

Katılımcıların pandemi sürecindeki ekonomik kaygılarından oluşan tema, var olanı koruma ve yoklukla mücadele alt temalarını içermektedir. Covid-19 sürecinde mevcut virüsle mücadele eden bütün ülkelerde olduğu gibi ülkemizde de ekonomik anlamda sıkıntılar baş göstermiştir. Pandeminin Türkiye'ye bir buçuk aylık dönemdeki faturası \%4,6 küçülme olarak yansımıştır (Fernandes, 2020). Futbol endüstrisinde ise ilk etapta seyircisiz oynanan maçlar ve sonrasında ertelenen ve iptal edilen ligler nedeniyle kulüpler biletleme, yayın gelirleri ve başarı primlerinden yoksun kalarak büyük ekonomik kayıplar yaşamıştır. Bu durumdan olumsuz etkilenen futbolcu katılımcılarımız, mevcut ekonomik durumunu koruyabilme ve yoklukla mücadele olarak kaygılarını belirtmişlerdir. Yapılan alan taramasında ise pandemi sürecinden insanların ekonomik anlamda kaygılarının arttığı belirlenmiş olup mevcut bulgular çalışmamızı destekler niteliktedir (Fetzer vd., 2020). Yine insanların Covid-19 sürecindeki duygularını belirlemeye yönelik bir başka çalışmada katılımcıların para ve işleri gibi ekonomik sebepler nedeniyle kaygı duydukları ifade edilmiştir (Kleinberg vd., 2020). Gerçekleştirilen diğer bir çalışmada ise Twitter kullanıcılarının kaygıları incelenmiş olup çalışma dahilinde incelenen katılımcıların mevcut ekonomik durumları nedeniyle kaygı duyduğu belirlenmiştir (Abd-Alrazaq, Alhuvail, Househ, Hamdi \& Shah, 2020). İnsanların Covid-19 kaynaklı kaygılarını ortaya koyan çalışmada ise insanların \%79 oranında genel ekonomi hakkında ve \%9 oranında işlerini kaybetme, ödemelerini gerçekleştirememe gibi kişisel ekonomileri hakkında kaygı duydukları belirlenmiştir (Mertens vd., 2020). Yukarıda ifade edilen Covid-19 sürecinin, ekonomiye olumsuz etkisini ortaya koyan bilgi ve bulgulara paralel olarak; gerçekleştirilen bu nitel çalışmada da paralel sonuçlara ulaştığ1 görülmektedir.

Katılımcıların fotoğraf ve hikayeleri sonucu belirlenen bir diğer tema olan gelecek kaygısı temas1 ise güzellikleri kaçırma, plan ve rutinleri ıskalama alt temalarından oluşmaktadır. Bu temaya dahil edilen hikaye ve fotoğraflar, ülkemiz ve dünyanın birçok noktasında uygulanan seyahat kısıtlamaları, karantina uygulamaları, maske kullanma zorunluluğu vb. durumların yaratmış olduğu belirsizlik nedeniyle katılımcılarda oluşan gelecek kaygısını kapsamaktadır. İnsanların gelecek kaygılarına yönelik yapılan alan taramasında bireylerin geleceklerine hükmedemeyeceklerini hissettiklerinde, içerisinde bulundukları durumla ilgili kaygı yaşadıkları belirlenmiştir (Tarhan, 2012). Çalışmamızı bulgularını destekler nitelikteki bir başka çalışmada ise Covid-19 pandemisinde insanların yaşamış oldukları sorunların incelenmesi sonucunda, katılımcıların gelecek kaygılarının yüksek olduğu belirlenmiştir (İbiş, 2020). Daha önce belirtildiği gibi pandemi süreci gibi zor zamanlarda yaşanan belirsizlik ve katılımcıların geleceklerine hükmedememeleri gelecek kaygısına neden olmaktadır. Literatürde gelecek kaygısı birçok kez işlenmiş olmasına rağmen pandemi gibi olağanüstü bir süreçte futbol bağlamında ortaya koymuş olduğumuz gelecek kaygısına ilişkin bulguların literatüre katkı sağlayacağ düşünülmektedir.

Çalışma dahilinde belirlenen son tema olan sağlık kaygısı teması yine aile bireylerine virüs bulaştırma ve kendini virüsten koruyabilme olmak üzere iki alt tema içermektedir. Dünya genelinde milyonlarca insanı hasta eden ve binlerce insanın ölümüne sebebiyet veren bununla beraber bilinen bir tedavisi olmayan virüse karşı katılımcıların yaşamış oldukları sağlık kaygıları, bu tema altında toplanmıştır. Katılımcılar kendi sağlıkları nedeniyle hissettikleri kaygı kadar aile bireylerinin sağlıkları hakkında da kaygı hissetmektedirler. Çalışmamızı destekler nitelikte yapılan bir araştırmada sorulan 
hangisini gerçekleşmesi seni kaygıya iter sorusuna, katılımcılar \%76 oranında bütün dünyanın hasta olması, \%39 arkadaşımın ya da ailemden birinin hasta olması ve \%30 oranında katılımcının hasta olması cevaplarını vermiştir (Kurl ve Korzinski, 10 Haziran 2020). Yine insanların pandemi sürecinde yaşamış oldukları sağlık kaygısını ortaya koyan bir başka çalışmada ise katılımcıların \%46'lık oranla sevdiklerinin hasta olması ve ölümlerinden kaygılandıkları ayrıca kişisel sağlıklarına yönelik kaygılarının ise \%11 oranında olduğu ortaya koyulmuştur (Mertens vd., 2020).

Her bilimsel araştırmada olduğu gibi bu nitel araştırmanında gerek metodolojik gerek kapsam bakımından kendine has sinırlılıkları bulunmaktadır. $\mathrm{Bu}$ araştırmadan elde edilen bulgular değerlendirilirken bu sınırlılıkların göz önünde bulunması gerekir. Araştırmamız nitel araştırmaların doğası gereği az sayıda katılımcıyla gerçekleştirilmiştir ve Türkiye liglerinde yer alan dokuz futbolcuyu kapsamaktadır. Her katılımcıya fotoğraf makinesi temin edilerek fotoğraflama yapmalarının istendiği fotoses yönteminde, günümüz pandemi sürecindeki kısıtlamalar nedeniyle katılımcılar kendi kameraları ile çektikleri fotoğraflara ek olarak internet ortamında kaygılarını temsil eden fotoğraflarla araştırmaya katılmıştır.

Az sayıda futbolcuyu kapsayan bu çalışma katılımcı sayısı arttırılarak gerçekleştirilebilir. Bununla birlikte ülkemizin 4 büyük takımı olan Galatasaray, Fenerbahçe, Beşiktaş ve Trabzonspor'dan futbolcularıla yapılacak görüşmeler daha geniş perspektif sunabilecektir. Sadece Türkiye liglerini kapsayan bu çalışmanın yanı sıra başka ülkelerden futbolcuların katılımıyla gerçekleştirilecek bir çalışma, daha genellenebilir sonuçlar verebilecektir.

\section{SONUÇ}

Virüsle ilgili aşının ve tedavinin bulunamamış olması, karantina ve önlem süreçleri, küresel ekonomik daralma ve belirsizlik sürecinin, katılımcıların kaygılarını oluşturduğu belirlenmiştir. Araştırma sonuçları, sporcuların psikolojik sıkıntılarının giderilmesi ve önlenmesi adına karar vericilere yardımcı olacaktır.

\section{ÖNERILER}

$\mathrm{Bu}$ araştırmadaki bulgular aracılığıyla devlet, yerel yönetimler, futbol konusunda karar vericiler (TFF, UEFA, FIFA) ve bu süreçten etkilenen paydaşlar politika ve çözüm geliştirebilirler. Önümüzdeki dönemde bir süre daha devam edebilecek olan mevcut pandeminin ve gelecekte yaşanabilecek başka virüs problemlerinin olumsuz etkilerini azaltacak önlemler konusunda yardımcı olacak niteliktedir. Araştırma bulguları ayrıca, sporcuların bir bakıma görmezden gelinen psikolojik ihtiyaçlarının karşılanmasına yönelik spor kulüplerine rehberlik edebilecektir.

\section{KAYNAKÇA}

Abd-Alrazaq, A., Alhuwail, D., Househ, M., Hamdi, M., ve Shah, Z. (2020). Top worries of Tweeters during the COVID-19 pandemic: infoveillance study. Journal of medical Internet research, 22(4), e19016. doi:10.2196/19016

Abdulamir AS, Hafidh RR. The Possible Immunological Pathways for the Variable Immunopathogenesis of COVID-19 Infections among Healthy Adults, Elderly and Children. Electron J Gen Med. 2020;17(4):em202. Erişim adresi: https://doi.org/10.29333/ejgm/7850

Alistair, M. (2020, 1 Haziran). N'Golo Kante: Chelsea will allow midfielder to stay away from training amid coronavirus fears, BBC. Erişim adresi: https://www.bbc.com/sport/football/52767877

Argan, M., Yılmaz, A., Argan, M. T., ve Yetim, G. (2020). Sesimi Gören Var mı? Fotoses Yönteminin Spor Bilimlerinde Kullanım Potansiyeline İlişkin Kuramsal Bir Çerçeve. Gazi Beden Eğitimi ve Spor Bilimleri Dergisi, 25(3), 149-166. Erişim adresi: https://dergipark.org.tr/en/download/article-file/1175472

Balaratnasingam, S., ve Janca, A. (2006). Mass hysteria revisited. Current Opinion in Psychiatry, 19, 171-174. doi: 10.1097/01.yco.0000214343.59872.7a

Booth, T. ve Booth, W. (2003). In the frame: Photovoice and mothers with learning difficulties. Disability \& Society, 18(4):431-442. Doi: 10.1080/0968759032000080986

Brooks, S. K., Webster, R. K., Smith, L. E., Woodland, L., Wessely, S., Greenberg, N. ve Rubin, G. J. (2020). The psychological impact of quarantine and how to reduce it: rapid review of the 
evidence. The Lancet. Trişim adresi: https://www.sciencedirect.com/science/article/pii/S0140673620304608

Büyüköztürk, Ş. (1997). Araştırmaya yönelik kaygı ölçeğinin geliştirilmesi. Kuram ve Uygulamada Eğitim Yönetimi Dergisi, 3(4), 453-464. Erişim adresi: http://kuey.net/index.php/kuey/article/view/683

Çalık, M. ve Sözbilir, M. (2014). İçerik analizinin parametreleri. Eğitim ve Bilim, 39(174), 33-38. Doi: 10.15390/EB.2014.3412

Dilmaç, B. ve Baş, A. (2019). Ergenlerin Sahip Oldukları Değerler, Öznel İyi Oluşları ve Sosyal Kaygıları Arasındaki Yordayıcı İlişki. MANAS Sosyal Araşstırmalar Dergisi, 8(4), 3685-3697.

Dinçer E. D. (2010). Biyolojik saat ve kaygının temel bilişsel işlevler üzerindeki etkileri. (Yayımlanmamış Doktora Tezi). Hacettepe Üniversitesi

Duncker, C. (2020, 25 Mayıs). Manchester United giving players psychological support during Covid19 pandemic. Erişim adresi: https://www.goal.com/en/news/manchester-united-giving-playerspsychological-support/u2i09nyap8f516zhqfujhp3q1, Goal.

Euronews, (2020, 1 Haziran). Fatih Terim koronavirüs (Covid-19) test sonucunun pozitif çıktığını açıkladı. Erişim adresi: https://tr.euronews.com/2020/03/23/fatih-terim-koronavirus-covid-19test-sonucunun-pozitif-ciktigini-acikladi

Fernandes, N. (2020). Economic effects of coronavirus outbreak (COVID-19) on the world economy. IESE Business School Working Paper No. WP-1240e. Doi: 10.2139/ssrn.3557504

Fetzer, T., Hensel, L., Hermle, J. ve Roth, C. (2020). Coronavirus perceptions and economic worry. arXiv. Erişim adresi: https://arxiv.org/pdf/2003.03848.pdf

Goal, (2020a, 24 May1s). Coronavirus and football teams: Which players, managers and owners are affected? Erişim adresi: https://www.goal.com/en/news/coronavirus-football-teams-playersmanagers-owners-affected/1unrxo89q54201k0nt2pyru972

Goal, (2020b, 24 Mayıs). Hangi ülkelerde futbol devam ediyor? Erişim adresi: https://www.goal.com/tr/haber/hangi-uelkelerde-futbol-devamediyor/hoamoy6k7a251q7cckq3a2b6q

Google, (2020, 20 Mayıs). Koronavirüs (Covid-19) Erişim adresi: https://news.google.com/covid19/map.

Goodhart, F. W., Hsu, J., Baek, J. H., Coleman, A. L., Maresca, F. M., \& Miller, M. B. (2006). A view through a different lens: Photovoice as a tool for student advocacy. Journal of American College Health, 55(1), 53-56. Doi:10.3200/JACH.55.1.53-56

Güner, H. R., Hasanoğlu, İ. ve Aktaş, F. (2020). COVID-19: Prevention and control measures in community. Turkish Journal of medical sciences, 50(SI-1), 571-577. Doi:10.3906/sag-2004146

Here To Help, (2020, 2 Haziran). Covid-19 and Worry. Erişim adresi: https://www.heretohelp.bc.ca/infosheet/covid-19-and-worry

Hofmann, S. G. ve Smits, J. A. (2008). Cognitive-behavioral therapy for adult worry disorders: a meta-analysis of randomized placebo-controlled trials. The Journal of clinical psychiatry, 69(4), 621. Erişim adresi: https://www.ncbi.nlm.nih.gov/pmc/articles/PMC2409267/

Horwitz, E. K. (2001) Language Worry and Achievement, Annual Review of Applied Linguistics, Vol. 21, pp. 112-126.

Huerta-P. (2004). Structural changes during a century of the world's most popular sport. Statistical Methods and Applications, 13(2), 241-258. Doi: 10.1007/s10260-004-0093-3

İbiş, S. (2020). Covıd-19 Salgınının Seyahat Acentaları Üzerine Etkisi. Safran Kültür ve Turizm Araştırmaları Dergisi, 3(1): 85-98. Erişim adresi: https://dergipark.org.tr/en/download/articlefile/1076683

Jones, J. H. ve Salathé, M. (2009). Early assessment of worry and behavioral response to novel swineorigin infl uenze $\mathrm{A}(\mathrm{H} 1 \mathrm{~N} 1)$. Plos $O N E$, 4, 1-8. Erişim adresi: https://doi.org/10.1371/journal.pone.0008032 
Kleinberg, B., Van der Vegt, I. ve Mozes, M. (2020). Measuring Emotions in the COVID-19 Real World Worry Dataset. arXiv preprint arXiv:2004.04225. Erişim adresi: https://arxiv.org/pdf/2004.04225.pdf

Kurl S. ve Korzinski D. (2020, 10 Haziran). Half of Canadians taking extra precautions as coronavirus continues to spread around the globe. Angusreid. Erişim adresi: http://angusreid.org/wpcontent/uploads/2020/02/2020.02.04_Coronavirus.pdf

Lau, J. T. F., Kim, J. H., Tsui, H. ve Griffiths, S. (2007). Perceptions related to human avian infl uenza and their associations with anticipated psychological and behavioral responses at the onset of outbreak in the Hong Kong Chinese general population. American Journal of Infection Control, 35, 38-49. doi:10.1016/j.ajic.2006.07.010

Leung, G. M., Ho, L. M., Chan, S. K., Ho, S. Y., Bacon-Shone, J., Choy, R. Y., Hedley, A. J., Lam, T. H. ve Fielding, R. (2005). Longitudinal assessment of community psychobehavioral responses during and after the 2003 outbreak of severe acute respiratory syndrome in Hong Kong. Clinical Infectious Diseases, 40, 1713-1720. Erişim adresi: https://doi.org/10.1086/429923

Lincoln, Y. S. ve Guba, E. G. (1985). Naturalistic inquiry. Newbury Park, CA: Sage Publications.

Liu, S., Yang, L., Zhang, C., Xiang, Y., Liu, Z., Hu, S. ve Zhang, B. (2020). Online mental health services in China during the COVID-19 outbreak. The Lancet Psychiatry, 7(4), e17-e18.

Lopez, E., Eng, E., Robinson, N. ve Wang, C. C. (2005). Photovoice as a community-based participatory research method. Methods in community-based participatory research for health, 326-348.

MacIntyre, P. D. (1995). How does worry affect second language learning? A reply to Sparks and Ganschow. The Modern Language Journal , 79 (1), 90-99. Erişim adresi: http://www.jstor.org/stable/329395

Merriam, S. B. (2013). Nitel araştırma. Desen ve Uygulama İçin Bir Rehber.(Çev. Editörü: Selahattin Turan). Nobel Akademik Yayıncılık.

Mertens, G., Gerritsen, L., Duijndam, S., Salemink, E., \& Engelhard, I. M. (2020). Fear of the coronavirus (COVID-19): Predictors in an online study conducted in March 2020. Journal of Anxiety Disorders, 102258. Erişim adresi: https://www.sciencedirect.com/science/article/pii/S0887618520300724

Povee, K., Bishop, B. J. ve Roberts, L. D. (2014). The use of photovoice with people with intellectual disabilities: reflections, challenges and opportunities. Disability \& Society, 29(6):893-907. Doi: 10.1080/09687599.2013.874331

Roy, D., Tripathy, S., Kar, S. K., Sharma, N., Verma, S. K. ve Kaushal, V. (2020). Study of knowledge, attitude, worry \& perceived mental healthcare need in Indian population during COVID-19 pandemic. Asian Journal of Psychiatry, 102083. Erişim adresi: https://doi.org/10.1016/j.ajp.2020.102083

Scovel, T. (1978) The Effect of Affect on Foreign Language Learning: A review of the Worry Research. In Horwitz, E. K. \& Young, D. J. Language Worry. PrenticeHall International, pp. 1525.

Spencer, J., (2020, 28 May1s). How's this for a lively conference call? Bayern Munich stars link up on Zoom for a 90-minute training session from home as coaches keep an eye on them... after taking a 20 per cent pay-cut to save the jobs of the club's low-paid staff. Dailymail. Erişim adresi: https://www.dailymail.co.uk/sport/football/article-8145933/Bayern-Munich-stars-ZoomBundesliga-giants-workout-video-conference-call.html

Statista, (2020, 15 Haziran). Main worries or concerns about the COVID-19 / coronavirus pandemic in the United States, United Kingdom and Germany 2020. Erişim adresi: https://www.statista.com/statistics/1107986/main-worries-and-worries-about-the-covid-19korona-pandemic/

Tarhan, N. (2012) Genç Arkadaşım. Timaş Yayınları. 
Taylor, M. R., Kingsley, E.A., Garry, J. S. ve Raphael, B. (2008). Factors infl uencing psychological distress during a disease epidemic: Data from Australia's first outbreak of equine infl uenza. BMC Public Health, 8(1), 347. Doi:10.1186/1471-2458-8-347

The Guardian, (2020, 5 Haziran). Football League clubs scramble to agree player wages deal in Covid-19 crisis. Erişim adresi: https://www.theguardian.com/football/2020/apr/10/efl-clubscoronavirus-crisis-wages-pfa-time-running-out

Türk Dil Kurumu (TDK), (2020, 10 Haziran). Erişim adresi: https://sozluk.gov.tr/

Türkiye Futbol Federasyonu (TFF), (2020, 24 May1s). https://www.tff.org/default.aspx?pageID=686

Wang, C. ve Burris, M. A. (1994). Empowerment through photo novella: Portraits of participation. Health education quarterly, 21(2):171-186. Doi: 10.1177/109019819402100204

Wang, C., \& Burris, M. (1997). Photovoice: Concept, methodology,and use for participatory needs assessment. Health Education and Behavior, 24, 369-387 Doi: 10.1177/109019819702400309

Xiang, Y., Yang, Y., Li, W., Zhang, L., Zhang, Q., Cheung, T. ve Ng, C. H. (2020). Timely mental health care for the 2019 novel koronavirus outbreak is urgently needed. Lancet, 7, 228-229.

Xu Z., Shi L., Wang Y., Zhang J., Huang L. ve Zhang C. (2020) Pathological findings of COVID-19 associated with acute respiratory distress syndrome. Lancet Respir Med, 8(4), 420-422. Erişim adresi: https://doi.org/10.1016/ S2213-2600(20)30076-X

\section{CITATION OF THIS ARTICLE}

Ünver, O., Dinç, H., Çetin, E. \& Argan, M. (2021) Kaygılarım Kabusum Olmasın! Futbolcuların Covid-19 Pandemisi Sürecindeki Kaygılarının Fotoses Yöntemiyle İncelenmesi. International Journal of Sport, Exercise \& Training Sciences - IJSETS, 7(2), 60-72. Doi: 10.18826/useeabd.934579 